\title{
A fina lâmina da palavra
}

Leda Martins I UFMG $^{1}$

\begin{abstract}
Resumo: Neste ensaio destacamos alguns aspectos da produção literária afrobrasileira e da reflexão crítica que a tem por objeto, visando contribuir para o debate e a investigação deste fértil repertório da escrita literária brasileira contemporânea.

Palavras-chave: Literatura afro-brasileira, Literatura negra, Crítica literária, Oralitura eperformance.
\end{abstract}

No conto Pai contra mãe, Machado de Assis tece uma das mais potentes descrições de dois aparelhos de tortura escravistas, a máscara de flandres e o ferro ao pescoço:

A Escravidão levou consigo ofícios e aparelhos, como terá sucedido a outras instituições sociais. Não cito alguns aparelhos senão por se ligarem a certo ofício. Um deles era o ferro ao pescoço, outro o ferro ao pé; havia também a máscara de Flandres. A máscara fazia perder o vício da embriagues aos escravos, por thes tapar a boca. Tinha só três buracos, dous para ver, um para respirar, e era fechada atrás da cabeça por um cadeado. (...) Era grotesca

1. Doutora em Literatura Comparada, pela UFMG. Pós-Doutorado em Teorias da Performance, pela New York University. Autora de vários livros, dentre eles A cena em sombras. Ed. Perspectiva, 1995; Afrografias da Memória. Ed. Perspectiva e Mazza Edições, 1997; Os dias Anônimos. Ed. Sette Letras, 1999. Profa dos cursos de Letras e de Artes Cênicas da UFMG. Poeta e ensaísta. 
tal máscara, mas a ordem social e humana nem sempre se alcança sem o grotesco, e alguma vez o cruel. Os funileiros as tinham penduradas, à venda, na porta das lojas (...) O ferro ao pescoço era aplicado aos escravos fujões. Imaginai uma coleira grossa, com a haste grossa também, à direita ou à esquerda, até ao alto da cabeça e fechada atrás com chave. ${ }^{2}$

A alusão a esses aparatos introduz uma narrativa minimalista, em cuja fábula dois dramas se interligam: o de uma escrava fugidia, Arminda, prestes a dar à luz, e o de seu persecutor, um caçador de escravos, na iminência de perder o próprio filho, bebê ainda, por carência financeira. No fim breve, a escrava aborta e seu persecutor, salvo pela recompensa da captura, rejubila-se com o filho entre os braços: "Cândido Neves, beijando o filho, entre lágrimas verdadeiras, abençoava a fuga e não se lhe dava do aborto. - Nem todas as crianças vingam, bateu-lhe o coração".

Talhados pelo estilete da escrita de Machado, a máscara de flandres, que silenciava o escravo, e o ferro ao pescoço, que lhe tolhia os movimentos, metonimicamente configuram as perversas relações de força e de poder entre senhores e escravos, sob as quais sucumbe tanto a vida do recém-nascido, como os mais nobres sentimentos, sentidos e experiência do humano. Referida pela sua literalidade de objeto desprovido de qualificativos, a máscara vaza nosso olhar, por feito da magistral escritura, da descrição minimalista, quase óssea, que a faz colarse à retina do leitor, num efeito de transferência dramático, aterrorizante e aterrador, ponte para uma sagaz e irônica reflexão do autor sobre a condição humana, assujeitada pela tortura, pela dor e pelo silêncio.

Em Machado, cumpre-se o que afirmava Cruz e Souza sobre outros mais nobres aparelhos, os da escritura: "Os utensilios da escrita são extraordinários, o jogo da frase é poderoso”. 'Machado de Assis e Cruz e Souza. Dois afro-brasileiros, mestres nos estilos e ofícios da escrita.

\section{As Grafias da Negrura nos Traços da Letra}

A produção literária dos afro-descendentes encontra nas últimas décadas uma atenção mais singularizada por parte de escritores e críticos que

2. ASSIS, 1975 , p. 49.

3. ASSIS, 1975 , p. 54

4. CRUZ E SOUZA, 1982, p. 86. 
buscam mapear uma tradição negra vernacular no âmbito da Literatura Brasileira, sublinhando o diverso leque de matizes e linhagens que traduzem a afrodescendência, caligrafada na e pela letra literária. A expansão do olhar sobre textos, autores, temas, situações e experiências, de certa forma até então exilados da reflexão crítica, dos meios e circuitos de veiculação e de reconhecimento, distende nossa cartografia literária e desafia as redes discursivas formadoras de juízo e de opinião. Do estudo dessas questões emergem suplementos imprescindíveis à história dos afro-descendentes no Brasil, em especial a história das muitas exclusões, hiatos, silêncios e lacunas dos discursos hegemônicos, mas, principalmente, emergem as vias e veredas engenhosas pelas quais a voz e a grafia afro-brasileiras insistentemente inscrevem a memória desse saber e dessa experiência, estética e ontológica, nos repertórios da cultura e da literatura.

Na literatura escrita no Brasil predomina a herança dos arquivos textuais e da tradição retórica européia. Mesmo os discursos que se alçaram como fundadores da nacionalidade literária brasileira, no século dezenove, tinham na série e dicção literárias ocidentais sua âncora e base de criação literária. A textualidade dos povos africanos e indígenas, seus repertórios narrativos e poéticos, seus domínios de linguagem e modos de apreender e figurar o real, deixados à margem, não ecoaram em nossas letras escritas. Bastide em 1943 já isto antes observara. Risério o reitera:

Quando os europeus principiaram a produzir textos no território hoje brasileiro, os indígenas já vinham, há tempos, produzindo os seus. E assim como os europeus transportaram para cá um dilatado e fecundo repertório textual, também os africanos, engajados à força no maior processo migratório de toda a história da humanidade, conduziram suas formas verbais criativas ao outro lado do Atlântico. Logo, ao se voltar pioneiramente para a história do texto criativo em nossa extensão geográfica, o romantismo deveria se defrontar, em tese, com os conjuntos formados por textos ameríndios e textos africanos. Em tese. De fato, não foi bem isto o que aconteceu. (...) O texto criativo africano foi ladeado ou ignorado, invariavelmente, naquele nosso ambiente. (...) Dito de outro modo, palavras negras passaram em brancas nuvens.

E é no âmbito de um código literário, no qual predominam as séries, o imaginário e as tradições retórico-discursivas européias, que o escritor afrodescendente exerce, principalmente a partir do século dezenove, o ofício das

5. RISÉRIO, 1993, p. 69-70. 
letras, no qual se destacam e ocupam um lugar ímpar escritores como Gonçalves Dias, Machado de Assis, Cruz e Souza e Lima Barreto, por exemplo, na contramão de contextos sócio-econômicos e inter-raciais adversos e restritivos:

Desde o período colonial, o trabalho dos afro-brasileiros se faz presente em praticamente todos os campos da atividade artística, mas nem sempre obtendo o reconhecimento devido. No caso da literatura, essa produção sofre, ao longo do tempo, impedimentos vários à sua divulgação, a começar pela própria materialização em livro. Quando não ficou inédita ou se perdeu nas prateleiras dos arquivos, circulou muitas vezes de forma restrita, em pequenas edições ou suportes alternativos. Em outros casos, existe o apagamento deliberado dos vínculos autorais e, mesmo, textuais, com a etnicidade africana ou com os modos e condições de existência dos afro-brasileiros, em função do processo de miscigenação branqueadora que perpassa a trajetória desta população.

A tradição letrada exige certas condições específicas de produção e de recepção para o seu exercício, condições essas também desfavoráveis ao negro africano e a seus descendentes. A escrita carece de leitores e de interlocutores. Os lugares de enunciação do escritor e os sujeitos de recepção da escrita, a maior ou menor mobilidade social e econômica de brancos, mestiços e negros, na sociedade em geral e nos meios letrados em particular; o acesso à formação escolar e aos meios de produção, os preconceitos, discriminações e exclusões do sistema são alguns dos fatores que não podem ser relevados quando analisamos, diacronicamente, a produção literária afro-brasileira. Sobre essas frágeis condições de recepção e de intercâmbios transformadores entre texto e leitores, no século XIX, afirma Oswaldo de Camargo:

... um Cruz e Souza não foi, como negro, um escritor natural, no sentido em que pudesse ( ao menos quando sua diç̧ão se pretendia negra) entabular intercâmbio com o negro de sua época; quando ele escreve, por exemplo, 'Emparedado', - o grito mais forte de um negro cercado de angústias neste País - duvidamos de que ele pudesse ou ousasse julgar estar-se dirigindo a negros. Ele era, no momento, os negros todos do País; ele tão somente se centrava sobre si mesmo, como escritor, quando o natural é que a obra se extrapole....

6. DUARTE, 2002, p. 47 
Portanto, a novidade 'revolucionária' que vem moldando a Literatura Afro-Brasileira ou negrista ou tão-somente negra é que ela se alimenta hoje de negros leitores ou possíveis leitores negros. (...) Um Cruz e Souza, um Lima Barreto, um Luiz Gama... não possuíam retornos para o que escreviam como negros.

Observando-se o contexto de enunciação de muitos desses escritores e a biografia de cada um deles, há que sempre e em quaisquer circunstâncias realçar o lugar ímpar que Machado de Assis, Mário de Andrade, Cruz e Souza e Lima Barreto ocupam, por sua maestria literária e sua importância cultural, no cânone da Literatura Brasileira, e a atenção devida a outros tantos escritores ainda pouco expostos ao olhar do público e da crítica, como, por exemplo, Luiz Gama e Solano Trindade, além, é claro, da fértil produção mais atual e contemporânea. A afro-descendência exprime-se de modo muito diverso na biografia desses autores, em sua dicção literária e, mesmo, nas aporias dramatizadas nos seus textos. A pletora de soluções literárias que se apresenta aos olhares do leitor, a alternância das linhagens e referências textuais, a diversidade de posturas autorais e identitárias, a maior ou menor ênfase na função pedagógica e exemplar da criação literária, as diferenças dos contextos e temporalidades dos escritores, assim como vários outros fatores, inerentes à lógica interna das criações e aos meios e ambientes de produção, traduzem algumas das dificuldades que resistem a qualquer tentativa de apreensão uniformizadora dessa zona de produção, sem que caiamos em anacronismos críticos redutores.

A vivência subjetiva da afro-descendência, em todas as suas dobras, transfigura-se, muitas vezes, em leitmotif da criação literária, mimeticamente encenada de forma polivalente e polissêmica, às vezes ambígua e pesarosa, às vezes irônica, utópica, transgressora. Laborada como memória do vivido e do devir, caligrafa-se por engenhosos artifícios e ficções, instalados na e pela letra literária, matizando os rastros e lastros pelos quais a negrura, indicialmente menos ou mais audível, em tons mais ou menos pálidos, com maior ou menor visibilidade, se inscreve, se encadeia e se postula, como experiência de linguagem. Experiência inclusiva que se dispõe na paisagem literária brasileira como tradução exemplar do diverso, percorrendo os amplos e sinuosos territórios retóricos e os vastos repertórios da linguagem criativa, que se estendem de Machado, mestre da letra escrita, às performances textuais das poéticas da oralidade.

7. CAMARGO, 1986 
Experiência ardilosa, glandular, carnavalesca, exercício lúdico da fina lâmina da palavra de Gama, que transforma em feito e efeito poético do diverso a mais densa, volumosa e terna face da negrura:

Lá Vai Verso

Ó musa da Guiné, cor de azeviche, Estátua de granito denegrido,

Ante quem o Leão se põe rendido, Despido do furor de atroz braveza; Empresta-me o cabaço d'urucungo, Ensina-me a brandir tua marimba, Inspira-me a ciência da candimba, Às vias me conduz d'alta grandeza.

Nem eu próprio à festança escaparei; Com foros de Africano fidalgote, Montado num Barão com ar de zote Ao rufo do tambor e das zabumbas Ao som de mil aplausos retumbantes, Entre os netos de Ginga, meus parentes, Pulando de prazer e de contentes Nas danças entrarei d'altas cayumbas.

Experiência dilacerante e dilaceradora com os carrilhões da linhagem poética, que pulsa de forma angustiadamente corrosiva na artesania de Cruz e Souza:

\section{"A Caveira}

I

Olhos que foram olhos, dous buracos Agora, fundos, no ondular da poeira...

Nem negros, nem azuis e nem opacos.

Caveira!

II

Nariz de linhas, correções audazes

De expressão aquilina e feiticeira,

Onde os olfatos virginais, falazes?!

Caveira! Caveira!!

8. GAMA, 1904, p. 58 
III

Boca de dentes límpidos e finos,

De curva leve, original, ligeira,

Que é feito dos teus risos cristalinos?!

Caveira! Caveira!! Caveira!!!

Experiência prazerosa das pulsações tímbricas e imagéticas nos fraseados da poética banto de Edimilson de Almeida Pereira:

Entre silêncio e som

riem tambores e sombras.

Os meninos criaram memória

antes de criar cabelos. ${ }^{10}$

Experiência multiconográfica da visualidade porosa de Arnaldo Xavier:

Balada Apocalírica n.. 1

coração que coração te fez coração

foi Jualê a serpente alada negra

que sonhou com todas as cores

Hey Jualê

na primeira vez

que saiu um pássaro do seu corpo

ela se viu caminho

e o vôo se fez de lágrimas

negro que negro se fez negro

foi Jualê a serpente Alda negra

que sonhou com todas as cores

Hey Jualê

na primeira vez

que saiu um caminho de seu corpo

ela se abriu em portas

e luou-se para que as lágrimas

entrassem como ventos

9. CRUZ E SOUZA, s/d.

10. PEREIRA, 1996. 
coração que coração te fez coração

foi Jualê a serpente alada negra

que sonhou com todas as cores

Hey Jualê

na primeira vez

que saiu uma porta de seu corpo

ela soluçou em chaves

vestida de chamas

negro que negro te fez negro

foi Jualê a serpente negra

que sonhou com todas as cores

Hey Jualê

na primeira vez

que saiu chamas de seu corpo

nos acendemos em sonhos ${ }^{11}$

Experiência oraliturizada nas cadências vocais dos orikis de Solano:

Olurum Ekê

Olurum Ekê

Olurum Ekê

Eu sou poeta do povo

Olurum Ekê

A minha bandeira

É de cor de sangue

Olurum Ekê

Olurum Ekê

Da cor da revolução

Olurum Ekê

Meus avos foram escravos

Olurum Ekê

Olurum Ekê

Eu ainda escravo sou

Olurum Ekê

Olurum Ekê

Os meus filhos não serão

11. XAVIER, apud BERND, 1992, p. 128-129. 
Olurum Ekê

Olurum Ekê $\hat{e}^{12}$

Experiência laminar da ferina potência transformadora da palavra a que nos arremete a poesia inquisitiva de Cuti:

Ela

A minha poesia

Sou eu que me desnudo

me descubro

Sou eu que me acho

e me cato

nos cantos encondidos

do sorriso agachado

A minha poesia

Sou eu rio que deságuo

nos teus olhos parados

Sou eu vento no moinho

do meu grito entalado

A minha poesia

Sou-eu-fome-de-muitos

punhos punhais

sombras fatais

e a esperança do mundo

no sangue vivo das palavras

A minha poesia

é som

é sã

é-sou

é soul

é sam

ba

tendo no couro branco do papel. ${ }^{13}$

12. TRINDADE, 1999, p. 55.

13. CUTI apud CAMARGO, 1987, p.201-202. 
Experiência desconstrutora da dicção feminina que pulsa nos textos de muitas escritoras, em cujos teares o labor da escrita, os adereços e arabescos da letra refiguram as imagens do feminino corpo da negrura, metonimicamente caligrafando nosso corpus literário.

\subsection{O Feminino Corpo da negrura}

Ao determos nosso olhar sobre a produção literária de Esmeralda Ribeiro, Conceição Evaristo, Míriam Alves, Elisa Lucinda e Geni Guimarães, por exemplo, não nos é difícil perceber que a letra ficcional e poética torna-se, em seus textos, um instrumento e um locus privilegiado para uma potente e persistente rasura, descontinuidade e desconstrução, tanto dos inumeráveis vícios de figuratização da persona negra feminina na literatura brasileira quanto de alçamento de uma voz alterna em relação ao racialismo e sexismo que permeiam oblíquas práticas discursivas. Tanto a tradição literária quanto seus engenhos retóricos-ideológicos são revisitados pelas lentes dessas escritoras, que plissam os itinerários familiares do nosso cânone, nele imprimindo e espargindo uma certa disritmia e dissonância tonificantes.

\section{Quem são essas escritoras?}

Numa entrevista de 1995, Miriam Alves, com a lúdica contundência que lhe é peculiar, afirmava:

O racismo do branco contra o negro, o sexismo do homem contra a mulher são similares. (...) Em geral a tendência da escritora negra é se engajar na luta do homem, chamada de geral. A especificidade de ser mulher escritora que aflora nos trabalhos passa então desapercebida.(...) Não preciso estar falando de chibata, escravidão, para escrever literatura negra. A arte é liberdade, libertação. A minha arte é engajada comigo. Eu sou o quê? Eu sou negra, mulher, mãe solteira, empresária, filha, funcionária, militante. (...) Se eu não consigo falar num conto, eu vou falar num poema. Se eu não consigo no poema, eu escrevo uma novela. Se eu não consigo numa novela, eu tento um romance. Se eu não conseguir em nada disso, quem sabe uma história em quadrinhos resolva? São os meus instrumentos. A literatura é o meu instrumento. Se eu conseguir me comunicar enchendo o papel de vírgula, e o leitor entender que eu estou falando do lugar onde o Brasil se instala, da miserabilidade em que a população negra se encontra, se eu conseguir falar com vírgulas, eu vou encher o papel de vírgula. ${ }^{14}$

14. ALVES, 1995, p. 971. 
É no corpo mesmo da escrita que este outro Brasil se performa e se instala, e que a arte se quer também como ofício de transfiguração, de rearranjo da memória e da história. Nos retalhos dos textos aqui aludidos, os significantes voz, corpo e memória são os atavios que tecem o corpo alterno e alternativo dessa escritura. Ali, em contrapontos, contraltos, sussurros, sobretons, a negrura jubilosamente se ostenta, como fios de uma linguagem que reinaugura, em cada pulsação rítmica, em cada expressão figurada, em cada gesto textual, as sete faces dessas silhuetas desdobráveis. Como nos anuncia o poema de Conceição Evaristo:

A noite não adormece

nos olhos das mulheres.

A lua fêmea, semelhante nossa, em vigília atenta vigia

a nossa memória. ${ }^{1}$

E são nesses ambientes de memória que o corpo se transveste em letra e esculpe uma produção literária singular. Em Guarde Segredo, conto de Esmeralda Ribeiro, o próprio ato de narrar torna-se veículo de transformação da memória do narrado, restaurado pela lembrança como um devir que transgride a narrativa matricial citada. A protagonista cumpre neste conto de Esmeralda um duplo papel, como personagem de um enredo ficcional, em cuja face se projetam e se deslocam tanto um modelo trágico exemplar, quanto a própria história literária e social que o sustenta. Nesse conto, Clara, uma jovem mulata, narra numa carta a uma amiga as peripécias de seu pretenso desaparecimento, após matar Cassi Jones, seu namorado. A nomeação dos personagens não é mera coincidência. $\mathrm{Na}$ história literária brasileira, Clara dos Anjos e Cassi Jones são personagens exemplares de um conto e de uma novela de Lima Barreto, Clara dos Anjos, cuja narrativa e peripécias Esmeralda Ribeiro brilhantemente destece e retece, quer nas artimanhas da fábula, quer na esboço e configuração dos personagens.

Em Barreto, a ingênua e meiga Clara sofre nas mãos de Cassi Jones, pequeno-burguês branco dos subúrbios cariocas, que a abandona grávida. A novela de Lima Barreto fecha-se com as lágrimas e desventuras de Clara, ecoadas no tom recriminatório e melancólico do narrador que critica a frágil educação familiar das jovens negras, vítimas fáceis do fetiche da brancura:

15. EVARISTO, 1996, p. 26. 
Clara saiu sem dizer nada, reprimindo as lágrimas, para que na rua não the descobrissem a vergonha. Então, ela? Então ela não se podia casar com aquele calaceiro, sem nenhum título, sem nenhuma qualidade superior? Porque?

Para que seriam aqueles cuidados todos de seus pais? Foram inúteis e contraproducentes, pois evitaram que ela conhecesse bem justamente a sua condição e os limites das suas aspirações sentimentais...

Foi ao encontro da mãe. Não lhe disse nada; abraçou-a, chorando. A mãe também chorou e, quando, Clara parou de chorar, entre soluços, disse:

- Mamãe, eu não sou nada nesta vida.

A Clara de Lima Barreto fulgura exemplarmente como figuratização de uma hamartia social, sucumbindo face a um desfecho previsto, predeterminado no escopo das mórbidas relações raciais no Brasil. Já a Clara de Esmeralda Ribeiro não veste o papel de vítima sacrificial, desfigurando os papéis e destinos do seu pré-texto. Ao dramatizar o enredo amoroso inter-racial, a escritora aborda o texto de Lima Barreto pela analogia temática, mas imediatamente dele se distancia, quer no alinhavo da trama quer na composição da persona feminina. Esculpida com novos adereços, sua protagonista inverte o destino da personagem de Barreto. Ela se livra do namorado pervertido e enfrenta, com altivez, o discurso racialista da exfutura sogra. No jogo intertextual e na fricção entre o texto exemplar da tradição literária e sua rasura, a narrativa de Esmeralda caligrafa um outro autógrafo na escrita do corpo feminino, assim como na escrita-corpus da literatura. O texto de Lima Barreto é contemplado não pelo apelo a uma filiação especular, mas por vias de uma relação descontínua e de descontinuidade que fissura e suplementa a narrativa precursora. Ao acessar o suplemento da diferença constitutiva, operadora de uma escritura alterna, a metaficionalidade passa a ser gerenciada não mais por uma mimesis especular e abismática, indicativa de uma repetição mortífera do mesmo, mas, sim, pela progressiva descontinuidade alusiva que torna o texto novo um moto-descontínuo, provocador de deslocamentos e de imagens transgressoras.

O destinatário da carta/conto engendra também um duplo vetor de recepção: tanto é a amiga da protagonista, quanto nós, seus leitores-narratários, tornados cúmplices da dupla subversão do sistema, feridos tanto pela protagonista quanto pela sua criadora. Podíamos aqui nos perguntar. Qual o papel de Lima Barreto nesta história? Tornado também personagem ficcional, num jogo de encaixes

16. BARRETO, 1990, p. 158. 
e desencaixes brilhante, Lima erra pela narrativa de Esmeralda Ribeiro, evocado dualmente como fotograma de uma película literária, e como fantasma da ficção, simultaneamente presente e ausente, visível e invisível, origem e perda da origem, verso e reverso que assombra o texto/casa de Clara. Ambiguamente celebrado e barrado, escrito e reescrito, esse personagem é recomposto por uma dicção narrativa que torna possível fazer coincidir, no texto contemporâneo, uma autoria transversal: os ideais de Lima Barreto escritor grafam-se na escrita de Esmeralda Ribeiro. No diálogo jubilatório entre as personas Barreto e Clara ouve-se:

$$
\begin{aligned}
& \text { - Você matou Cassi Jones? - ele interrompeu o meu devaneio. } \\
& \text { - Matei - respondi. "Como soube disso", interroguei-me. } \\
& \text { - Bravo! Esse era o outro final que queria para o cafajeste do Cassi } \\
& \text { Jones. }
\end{aligned}
$$

Sobre o cadáver de Cassi Jones, a narrativa atual celebra o predecessor justamente por deslocar suas soluções e contextos, reconfigurando as alternativas e soluções de fabulação da trama. Como um suplemento transcriador, a narrativa atual cita a tradição, celebrando o autor, mas plissando e consertando a dicção e os destinos da mulher ali e aqui tornada objeto da ficção, mas não só. Os referenciais da tradição literária, quer da série autoral, quer da fabulação romanesca, recitados em estado de diferença, apropriados e reescritos de forma alterna, traduzem o duplo movimento de afinidade e distanciamento, de evocação e deslocamento da narrativa, saborosamente evocados pela avó da pós-moderna Clara: "Tinha que ser assim, minha neta... Nós não devemos aceitar o destino com resignação." ${ }^{18}$

Ao final de sua narração, Clara pede à amiga que guarde segredo. Este guardar segredo pode ser lido como um ato de um recesso voluntário e estratégico que o expediente retórico recobre. Resguardando, na esfera do privado, o ato transgressor, tornado, no entanto, público pela inconfidência da escritura, o apelo de Clara dramatiza a tensão entre a necessidade do silêncio e o desejo de uma elocução em sustenido, ou, como afirma Carole Boyce Davies, a tensão entre "articulação e afasia", "entre o espaço para certas formas de discurso e a falta de espaço para o discurso da mulher negra, a sua postulação entre o público e o privado" .

17. RIBEIRO, 1991, p. 29.

18. RIBEIRO, 1991, p. 29.

19. DAVIES, 1994, p. 153. 
Os deslocamentos simbólicos e espaciais da protagonista apontam um traço marcante em muitos desses textos: o tema do trânsito e das metamorfoses, trânsito esse obsessivamente desenhado sobre ou por uma tessitura líquida, fluida, evocada por correntes, jorro, rios, sangue, que escorrem, como se materializassem na imagem plástica a odisséia de uma viagem em que a Ítaca desejada nunca é o além de um porto seguro, de um descanso venturoso e épico, mas, sim, o domínio da própria linguagem, esta, sim, objeto de perquirição. É na e pela linguagem que a odisséia se realiza, pois é nesta travessia que as metamorfoses têm lugar. O corpo, em contínuo processo de deslocamento e de ressignificação, torna-se ele próprio uma geografia, uma paisagem, um território de linguagens, um continente sem fim trespassado de palavras:

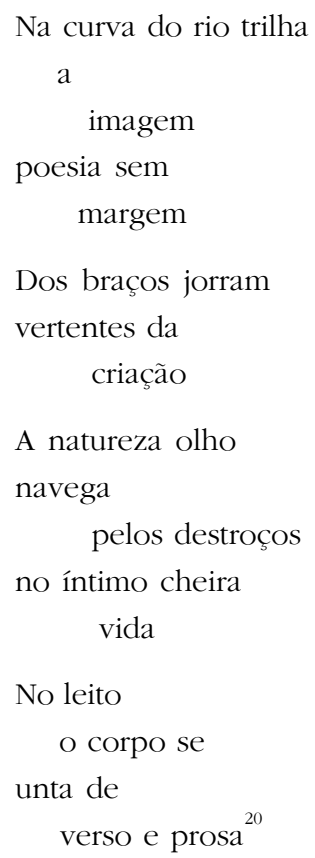

Na geografia do corpo feminino, oferecido como pauta para inscrição de um saber íntimo, a auto-imagem fotografa-se em retalhos assimétricos, granulada por um alto índice de vocalidade:

20. RIBEIRO, 1995, p. 82. 
Uma gota de leite
me escorre entre os seios.
Uma mancha de sangue
me enfeita entre as pernas.
Meia palavra mordida
me foge da boca.
Vagos desejos insinuam esperanças.

Nesse poema de Conceição Evaristo, a metáfora dos rios vermelhos abriga a itinerância da mulher, provisoriamente alojada em cada pré nome que gradativamente a constitui como um sujeito em processo de auto-reconhecimento. Em vinte e um versos, o pronome "eu" repete-se oito vezes em sua forma pessoal e mais três em modulações oblíquas, como prenúncio de uma auto-nomeação em processo de devir.O movimento desse eu, sujeito de sua própria enunciação, engravida o texto de referências prefaciadoras, citando o corpo da mulher como uma paisagem perenemente reinaugurada por ela mesma:

Eu-mulher
abrigo da semente
moto contínuo
do mundo.

Reencenado em vários lugares e tempos descontínuos, esse eu-shifter aporta sempre provisoriamente, traduzindo, pela reiteração da metáfora, a migração e a metamorfose da figura feminina. A viagem é, assim, sempre inaugural, alquímica, uma contínua transformação do silêncio em linguagem e em ação. Como observa Collins, "essa jornada para a auto-definição tem significância política", pois "oferece um poderoso desafio às imagens controladoras que externamente definem a mulher". ${ }^{23}$ Uma dicção jubilatória incide agora no corpo da escrita, esvaziada dos sentidos opacos, das figurações alheias e alienantes, como neste belo poema de Miriam Alves:

21. EVARISTO, 1995, p. 70.

22. EVARISTO, 1995, p. 70.

23. collins, 1991, p. 106. 


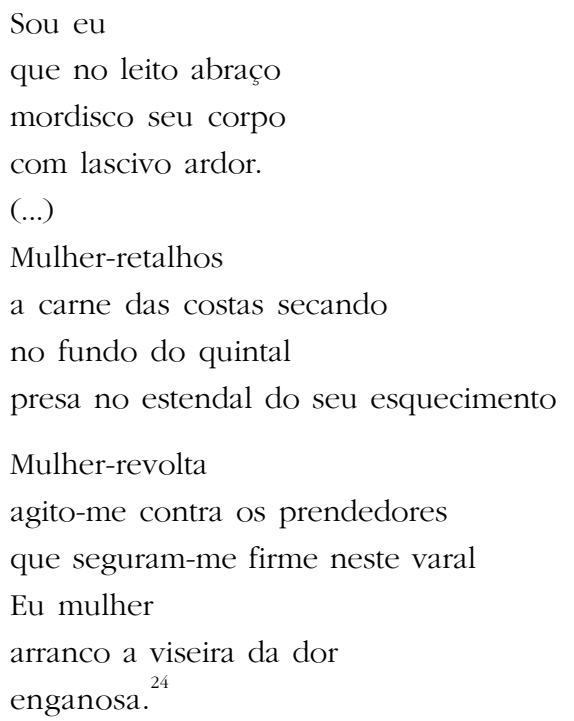

Restituído em seus predicados e amavios esse eu/shifter pode agora oferecer-se ao outro, como locus de um conhecimento próprio, como corpo de enunciação:

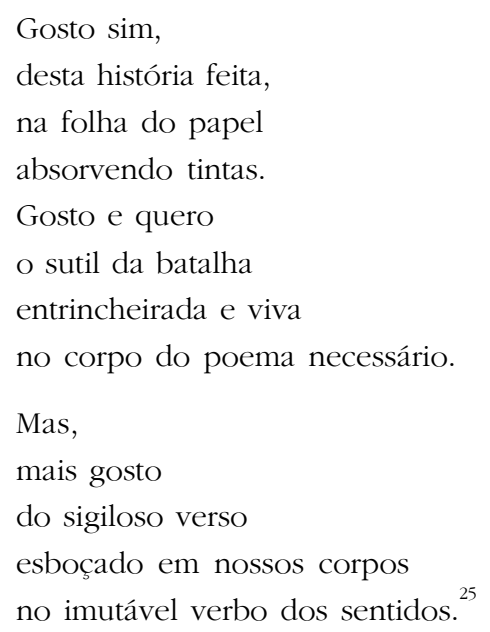

Ou como ainda versa a mesma Geni Guimarães:

24. ALVES, 1995, p. 969.

25. GUIMARÃES, 1995, p. 102. 
Tanto fez para desfazer

tanto sangrou pra não sangrar

tanto aspirou

cuspiu

bebeu

se deu, lutou

que ao se vencer, se amou.

Hoje exibe a negra bela cara

ao sol ardente que reveste a rua.

Satisfaz-se

A vida é uma cabeça.

A consciência é sua. ${ }^{26}$

Um traço estilístico marcante ressoa desses textos, aludindo a uma técnica de composição que podemos denominar de retórica de retalhos, na qual os objetos, situações, figuras e temas evocados são elaborados de restos e resíduos do cotidiano, alinhavados numa partitura que prima pela justaposição de contrastes, cores, desenhos e traçados aparentemente destoantes e desalinhados, que se conformam numa uniformidade assimétrica, como um tecido que se fabricasse por um ritual corriqueiro de uso do diverso. A artesania da escrita é o fio que transforma esses retalhos e resíduos do cotidiano em novos engenhos de linguagem que, como arabescos, revestem o corpo da negrura e o corpus de nossa literatura:

Moço, cuidado com ela...

Cuidado com cada letra que manda pra ela!

Tá acostumada a viver por dentro, transforma fato em elemento

a tudo refoga, ferve, frita

ainda sangra tudo no próximo mês. ${ }^{27}$

A literatura dessas escritoras posa para nossos olhares, desafiando nossas certezas, solicitando nosso próprio labor crítico. Por que ignorá-las? Afinal, como afirma Toni Morrison, "all of us, readers and writers, are bereft when criticism remains too polite or too fearful to notice a disrupting darkness before its eyes."

26. GUIMARÃES, 1995 , p. 96.

27. LUCINDA, 2000, p. 123.

28. MORRISON, 1992, p. 91. 
Em versos e prosa, a própria memória de nosso país se reescreve, pontilhada nas frestas e nos retalhos de uma escritura que se insubordina contra o lugar-comum da repetição estereotípica, almejando uma edição nova não apenas do discurso literário, como também da própria história social e cultural ali caligrafada. Esses textos nos convidam a frui-los, num exercício de pensamento e de degustação consoantes, pousados numa poiesis que busca provocar, em sua recepção, uma transformação da própria experiência estética que se almeja mobilizante e mobilizadora. Assim:

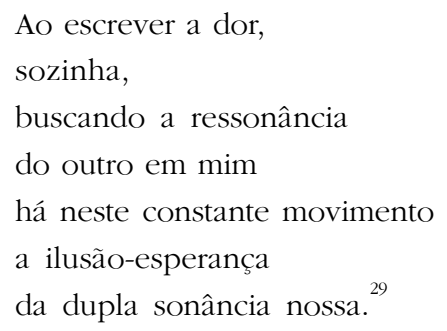

\section{Os Contornos da Crítica}

Toda essa variedade de dicções literárias vêm despertar na crítica literária brasileira, principalmente a partir dos anos oitenta, uma atenção particular, tomando vulto, na voz de escritores e de críticos, um fértil debate sobre a propriedade de se nomear como negra ou afro-brasileira certas zonas de produção literária no Brasil. Apesar de essas designações e termos já virem sendo esporadicamente utilizados desde os anos trinta, seu uso revestia-se, agora, de diferentes contornos semânticos, de novas ênfases e perspectivas teóricas que buscavam perquerir e abordar a produção literária dos afro-descendentes, no âmbito da literatura e da cultura brasileiras, por meio de vieses diferenciadores, visando: 1) ampliar, em particular no contexto acadêmico, a reflexão crítica e a pesquisa historiográfica, de modo a mapear e distender a cartografia inclusiva da afrodescendência, no amplo e diverso contexto de possibilidades de suas realizações literárias, com aportes teórico-metodológicos que incluíssem suas diversidades de linhagens e de opções estéticas; 2) discutir as condições de produção, recepção e circulação dessa literatura, conotando nos significantes negra, afro-brasileira e, mais 
recentemente, afro-descendente, as tensões raciais, étnicas, sociais e culturais, histórica e ideologicamente aderidas no cânone literário e nas relações de força ali disseminadas, nas condições de veiculação e veridicção dessa produção, assim como nas relações de poder do negro em vários âmbitos da própria sociedade brasileira; 3) realçar, epistemologicamente, e valorar, sob prismas teóricometodológicos apropriados, os repertórios textuais da oralidade, dentre eles os originários, matricialmente, das culturas africanas e nativo-indígenas, nos quais gravitam singulares propriedades, técnicas e procedimentos de composição, em um celeiro de variadas formas poéticas e narrativas.

Muitos fatores determinaram o alçamento dessas questões desde fins dos anos setenta. A emergência do Movimento Negro, no contexto de abertura política que anunciava os fins da ditadura militar. A afirmação e eleição do 20 de Novembro como data celebrativa do negro brasileiro, em memória de Zumbi e da República de Palmares, que vêm juntar-se ao leque de movimentos ativistas e reinvidicatórios que se impõem na época, dentre eles o Feminista. Os movimentos de escritores negros, reunidos em várias congregações. Grupos como o Quilombhoje, fundado em São Paulo em 1978, e o Negrícia, do Rio de janeiro, por exemplo, cumpriam uma função exemplar no estímulo à criação e no fomento de discussões literárias, postulando, ativamente, o reconhecimento de uma tradição negra, passada e presente, no âmbito da Literatura Brasileira, avessos à figuratização estereotípica e periférica de temas e personagens negros no bojo de nossa literatura e ao predomínio dos lugares de exclusão reservados aos afro-descendentes no contexto da sociedade. Livros editados pelos próprios autores, como o de Adão Ventura, $A$ Cor da Pele, publicado em 1980, tonificam o ambiente. Nos poemas de Adão, os crivos da pele, rabiscando as memórias do corpo, sulcam a geografia da história do negro, tensionados pelos voleios e cortes da linguagem:

\footnotetext{
Papai-Moçambique

papai-moçambique

- viola e sapateio

- desafio de versos

fogosos.

papai-moçambique

senta pé na fogueira
} 


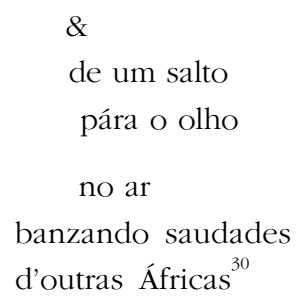

A postulação e afirmação de uma literatura negra, por si sós, nos anos oitenta, fomentavam o debate sobre questões polêmicas: tem a literatura cor, etnia, raça, gênero, língua? À maneira de Borges, jovens e, ainda, desconhecidos autores instauravam e reivindicavam uma tradição vernacular negra, dentre as várias que cartografam os territórios das linguagens literárias no Brasil. De norte a sul do país, escritores como Oswaldo de Camargo, Abelardo Rodrigues, Luiz Silva, o Cuti, Miriam Alves, Esmeralda Ribeiro, Paulo Colina, Geni Guimarães, Arnaldo Xavier, em São Paulo, Oliveira Silveira e Ronald Augusto, em Porto Alegre, Jônatas da Conceição, em Salvador, Lepê Correia, em Recife, Ele Semog, Domício Proença Filho, e Conceição Evaristo no Rio, Adão Ventura e Ricardo Aleixo, em Belo Horizonte, e Edimilson de Almeida Pereira, em Juiz de Fora, dentre muitos outros, imprimiam novas tinturas e posturas étnicas em sua dicção literária.

Parte da produção desses autores, publicada em antologias independentes, começa a despertar o interesse de estudiosos estrangeiros que, também em coletâneas, passam a divulgá-los no exterior. Destacam-se dentre as edições brasileiras os já hoje célebres Cadernos Negros, publicação do Quilombhoje que, desde 1978, é editado anualmente, divulgando autores de várias regiões, mantendo também uma fértil interlocução com escritores de outros países, em particular, africanos e afro-americanos. Sobre a importância desses encontros, edições e grupos, desses novos "quilombos de palavras", Florentina Souza afirma:

Há mais de vinte anos vem se firmando no cenário da produção textual do País um conjunto de vozes que, articulando criação e protesto, definese como literatura negra ou afro-brasileira. Os autores desses discursos são afro-descendentes que iniciaram uma publicação sistemática de seus textos por volta dos finais da década de setenta, constituindo um circuito editorial alternativo- um quilombo de palavras poéticas, que de modo similar aos quilombos históricos, estrutura-se como símbolo de resistência

30. VENTURA, 1980, p. 18. 
e preservação cultural que viabiliza a afirmação identitária e da autoestima. (...) Compreendendo a produção literária como espaço para, entre outros propósitos, interferir nas várias instâncias de poder e de representação, essa literatura busca reverter sentidos, encadear e explorar as possibilidades de forjar significados e conexões, regatar histórias e tradições de origem africana, ou seja, apoderar-se também do sistema de produção de imagens e significados. ${ }^{31}$

No Cadernos Negros n. 7, de 1984, Luiz Silva, o Cuti, reiterava os compromissos estéticos e políticos que fomentavam utópica e ativamente as atividades dele e de tantos outros escritores, na época:

Tenho a preocupação de conscientizar através da minha literatura, comunicar determinados sentimentos - em particular o sentimento negroporque, enquanto negro, não posso me furtar à experiência de minha condição humana, alegre e triste. (...) Acho também que não há literatura negra sem literatura. A questão do trabalho literário é fundamental. ${ }^{32}$

Esse trabalho de artesania com a linguagem literária era também saudado por Ricardo Aleixo, jornalista e escritor, ao sublinhar nos livros de outro jovem autor, Edimilson de Almeida Pereira, os toques de uma poética inventiva, que brincava, com intimidade e labor, com a pletora de possibilidades estilísticas dispostas nos repertórios de textualidades da cultura afro-brasileira, transcriando "uma tecnologia poética especificamente negro-africana ou afro-brasileira, apreendida principalmente na estrutura rítmico-lexical dos cânticos de louvor (orikis) das religiões negras", refazendo "no limite da palavra escrita (e do livro enquanto invólucro precário), a textualidade afro-mineira: rítmica, eufônica, plástica”."

Em 1987, Osvaldo de Camargo publicava O Negro Escrito, apontamentos sobre a presença do negro na Literatura Brasileira, uma obra seminal, por suas inclusões e posicionamento face às muitas questões então emergentes. Nesse livro, Camargo revisita a historiografia literária brasileira, trazendo à nossa escuta ensaios sobre autores ignorados, assim como discussões atuais sobre a obra de escritores já reconhecidos, além de apontar, criticamente, em parte da produção mais recente da época, a sobreposição dos reclames intimistas, dos gestos

31. SOUZA, 2000, p. 9.

32. CUTI, 1984, p. 6-7.

33. AlEiXo, 1989, p. 6. 
identitários e de pertencimento, ao árduo e necessário trabalho de elaboração com a linguagem poética. No Prefácio à obra, Paulo Colina se manifestava sobre algumas das questões suscitadas por Camargo:

Por experiência, sei que toda vez que o negro escrito aparece em um debate, uma conferência, palestra, surgem, de pronto, as perguntas de rotina: "Mas, por que literatura negra? Existe? A literatura tem cor?" E sou obrigado a retroceder às análises que tenho feito desde que me confronto com o mundo. Para chegar à conclusão de que à sociedade pátria interessa o negro mudo. Tudo uma questão de voz. (...) Assim, nada mais importante que esse O NEGRO ESCRITO de Oswaldo de Camargo. Para provocar novas discussões e resgatar a voz de autores esquecidos. ... há o mérito de trazer à tona o mais antigo editor brasileiro, poeta e precursor da Imprensa Negra (em 1833), Paula Brito. O homem que revelou Machado de Assis. De Minas, ainda, Camargo nos traz Henrique de Rezende e Guilhermino César, ambos da Revista Verde, de Cataguases, editada em pleno Modernismo. Guilhermino, inclusive, foi um dos fundadores da LEITE CRIOULO, revista negra, no clima de 22. (...) Necessário repensar o que transparece neste livro: após mestre Lima Barreto, o que houve com a prosa ficcional do negro brasileiro? Por outro lado, a nossa literatura contemporânea negra é mapeada a partir de Solano Trindade. Estariam os trabalhos dos poetas negros atuais pendurados entre o social de Solano e o intimismo, o eu, de Cruz e Sousa?

Toda essa variedade de dicções literárias gera na crítica literária uma atenção particular. O despertar dessa mirada crítica, àquela altura ainda tímida e incipiente, foi também motivada e alimentada por outros aportes. No âmbito das reflexões teóricas desconstrutivistas que reconfiguravam o olhar crítico sobre as literaturas nacionais dos países colonizados e economicamente periféricos, em relação aos modelos advindos de nações hegemônicas, realçando as diferenças culturais e as singularidades textuais, ressoavam, mais insistentemente, certas indagações sobre a formação do próprio cânone literário brasileiro e as inúmeras exclusões e lacunas, de gênero, raça e etnias, na eleição de autores e obras que o compõem. No âmbito desse amplo leque de questões, as expressões literatura negra e literatura afro-brasileira passam a circular mais ostensivamente, no meio acadêmico e artístico, fomentando um polêmico debate conceitual.

34. COLINA, 1987, p. 11. Grifos do Autor. 
Alguns fatos e tendências marcantes também contribuem para essas discussões, dentre eles: as reflexões suscitadas sobre as Literaturas Africanas de Língua Portuguesa; as relações dessas literaturas com a Brasileira; o papel da oralidade e a função política dessas literaturas nas lutas pela independência das então jovens nações africanas, o que contribuía para a veiculação dos textos de autores africanos como Craveirinha, Agostinho Neto, Luandino Vieira, Pepetela, dentre outros, em algumas zonas e circuitos intelectuais brasileiros; as revisões e repercussões dos movimentos da Negritude e sua importância nas literaturas negras das Américas Caribe, pelas quais autores como Senghor, Fanon, dentre outros, eram referidos; as ressonâncias, no Brasil, dos movimentos políticos, artísticos, culturais e reinvidicatórios dos negros norte-americanos, e a crescente circulação de textos de escritores afro-americanos no Brasil, dentre eles Langston Hughes, Amiri Baraka e Alice Walker; as ressonâncias dos movimentos internacionais pela libertação de Mandela e contra o apartheid sul-africano. Acrescente-se a todo esse contexto o crescimento quantitativo e qualitativo de pesquisas de fôlego sobre a ativa e decisiva contribuição dos africanos e de seus descendentes na formação nacional, em várias áreas de conhecimento, sejam elas linguísticas, artísticas, tecnológicas, históricas, religiosas; além da própria emergência, nos anos oitenta e noventa, de intelectuais negros, muitos deles professores universitários, que em várias áreas do conhecimento, tomam por objeto de pesquisa e de reflexão aspectos os mais diversos da ampla, variada e decisiva experiência e história do negro no Brasil, desvelando, por exemplo, a importância de movimentos como a Frente Negra e a Imprensa Negra, o Teatro Experimental do Negro, investigando as línguas e dialetos africanos no Brasil, as religiões afro-brasileiras, dentre inúmeros outros temas direta ou indiretamente relacionados à criação textual, escrita e oral. $\mathrm{Na}$ mesma época, a crítica de gênero reedita o romance Úrsula, publicado em 1859 por Maria Firmina dos Reis, primeira romancista negra brasileira, e reativa-se o debate sobre a obra de Carolina de Jesus.

No âmago dessa fermentação alguns conceitos sobre a literatura negra vêm à tona. Em 1987, Zilá Bernd destaca como um dos traços da produção afrobrasileira mais contemporânea o perfil auto-nomeador, designando como literatura negra textos nos quais o discurso poético exibe a negrura como marca de linguagem e de asserção identitária autoral. A mesma ensaísta, na organização da antologia Poesia Negra Brasileira, de 1992, enfatizava esses argumentos: 
Para nós, o único conceito aceitável de literatura negra é o que se alicerça nas constantes discursivas das obras. Logo, em nossa perspectiva, não será apenas a utilização de uma temática negra (o negro como objeto), nem a cor da pele do escritor (critério epidérmico) o que caracterizariam a existência de uma literatura negra, mas a emergência de um euenunciador que se assume como negro no discurso literário. ${ }^{35}$

Os aportes de Bernd desdobravam o uso do termo negro, introduzindo um deslocamento epistemológico polêmico, compreendendo a configuração do eu poético em um lugar de enunciação identitária, em que a subjetividade encenada pelo discurso marcaria a apropriação de uma linguagem, de uma cor, de uma raça, eleitos como referências residuais mimetizadas como texto. Em 1995, no livro $\boldsymbol{A}$ Cena em Sombras, detendo nosso olhar sobre a criação dramatúrgica e cênica do Teatro Experimental do Negro, fundado por Abdias do Nascimento em 1944, postulávamos a possibilidade de se qualificar um teatro negro por eixos teóricos e metodológicos que: a) sublinhavam os parentescos estilísticos, textuais e teatrais de suas produções com o imaginário e com as tradições performáticas afro-brasileiras e africanas, elegendo operadores teórico-conceituais oriundos dos princípios cognitivos e de visão de mundo ali reelaborados; b)apontavam os intercâmbios de repertórios nas estruturas de composição cênica e dramatúrgica entrecruzadas na linguagen e na performance teatral, em particular os oriundos dos rituais afrobrasileiros; realçávamos, ainda, no TEN, a reficcionalização da persona negra como corpo de memória do conhecimento, conotando o adjetivo negro como uma episteme, um saber e, não apenas, como uma epiderme, uma causa, um lamento ou um pesar.

A reiterada ênfase, por escritores e críticos, nos significantes literatura negra, afro-brasileira e, mais recentemente, afro-descendente, as tentativas de conotações teórica, crítica e ideológica, e mesmo a flutuação terminológica, traduzem o fermento e o fomento das discussões que têm aguçado os debates sobre o tema, nos últimos anos. Os termos, seus usos e propriedade nos revelam que na ordem da cultura, e em particular, em uma de suas expressões, a literatura, as questões ali instaladas encontram um fértil e necessário ambiente para nossa reflexão. Já em 1987, no livro O Negro Escrito, Osvaldo de Camargo, comentando o próprio uso reiterado da palavra negro nessa sua obra, vislumbrava sua conotativa necessidade, como postura estética e ideológica, ainda que provisória:

35. BERND, 1992, p. 13. Grifos da autora. 
Talvez em nenhum texto literário editado neste país se tenha sublinhado tanto a palavra negro. No entanto, é a que nos resta, como demarcação. Território vocabular mínimo - duas sílabas - sobre ele deve pousar um dia, pra valer, a Esperança (três). Vai caber?

Todo nosso esforço - com a Literatura Negra, que vamos espalhando por aí - é no sentido de que a Esperança chame a Igualdade e, juntas, se amoldem e conosco permaneçam. Literatura serve também para isso.

Essas atitudes inclusivas e inquiridoras, teóricas e historiográficas, mapeiam os cenários dessa produção, diacrônica e sincronicamente, nomeando a afro-descendência como uma das grafias e inscrições na Literatura Brasileira, realçando os múltiplos matizes de figuratização e encenação da negrura em autores já consagrados, como Machado de Assis, Cruz e Souza e Lima Barreto; ou sublinhando escritores menos visíveis ao olhar e à leitura do público e da crítica, como, por exemplo, Luiz Gama, Auta de Souza, Lino Guedes, João do Rio, Solano Trindade, Carolina de Jesus, Oswaldo de Camargo, Arnaldo Xavier, Oliveira Silveira, Cuti, Miriam Alves, Abdias do Nascimento, Adão Ventura, Geni Guimarães, Esmeralda Ribeiro, Conceição Evaristo, Éle Semog, Edimilson de Almeida Pereira, Ricardo Aleixo, Márcio Barbosa, Domício Proença Filho, Paulo Colina, Elisa Lucinda, Ronald Augusto, Jônatas Conceição, alguns dos muitos autores que com maestria e engenho têm traduzido, esteticamente, a experiência negra em seus textos sob singulares e diversos matizes, percorrendo modos de elaboração, apreensão, atitudes e tendências escriturais diversos. No entanto, como nos ensina o próprio Osvaldo de Camargo, "não se completa com citações de alguns nomes o corpo de uma literatura". A leitura dessa diversidade de textos e de posturas resiste a toda e qualquer tentativa de apreensão crítica generalizante e uniformizadora, exigindo de seus leitores a atenção individualizada e o rigor analítico que cada obra e cada texto, como objeto estético, carece para sua mensuração e interlocução apropriadas. O que essa produção nos solicita não é a condescendência, tão preconceituosa quanto a denegação e o ocultamento, mas, sim, a atenção crítica meticulosa que a nervura do texto impõe, na análise da extensa gama de aspectos entrecruzados que se oferecem à nossa fruição. Afinal, como já postulava Cuti em 1984, "não há literatura negra sem literatura". O viés identitário, o revisionista, o historiográfico, o discursivo, o performático, dentre outros, podem nos fornecer entradas fecundas na algaravia

36. CAMARgo, 1987, p. 110-111.

37. CAMARGO, 1987, p. 107. 
dessa produção, tanto da mais longíngua quanto da mais recente, mas se tornam redutores, se postulados como sínteses exclusivas e totalizadoras da experiência, antes de tudo, literária. Em um breve ensaio de 1995, intitulado Transnegressão, Ronald Augusto apontava, com muita pertinência, alguns dos riscos inerentes nas catalogações dessa produção. Referindo-se tanto "à organização de antologias fortemente temáticas onde os conteúdos inessenciais se sobrepõem à realização poética mais penetrante", quanto à "publicação de ensaios que investigam estes objetos literários tão só como exemplos de uma afirmação identitária, cuja função seria a de amplificar e dar nobreza documental aos anseios de uma coletividade ou segmento racial", assim como à sobrevalorazão de uma "essência", transvestida na demanda de uma "consciência negra", Ronald argumentava:

O grande dano deste traçado programático, delimitador (...) é a exclusão sumária de outros textos/autores que apontam hoje - ou que apontaram no passado- para zonas limiares, imprecisas, abertas ao viés da provisoriedade, onde a inteligência em progresso costuma puxar o tapete à mediocridade conformadora; o esforço dos poetas/escritores que focalizam a sua atenção mais no como dizer e menos, bem menos, no que é urgente dizer talvez ao ouvido do pesadelo da História. ${ }^{38}$

\section{Os Saberes da Oralitura}

Dentre essas zonas e forças limiares, uma das mais férteis remetenos ao âmbito da textualidade oral e das performances rituais, no seio das quais muitas formas poéticas e ficcionais se dispõem. Ali, a palavra poética, cantada e vocalizada, ressoa como efeito de uma linguagem performática do corpo, inscrevendo o sujeito emissor, que a porta, e o receptor, a quem também circunscreve, em um determinado circuito de expressão, potência e poder. Como sopro, hálito, dicção e acontecimento performático, a palavra proferida e cantada, numinosa e aurática, grafa-se na performance do corpo, portal e índice da sabedoria. Como agente de conhecimento, a palavra não se petrifica em um depósito ou arquivo estático, mas é, essencialmente, kinesis, movimento dinâmico. Solano Trindade já expressava o desejo de buscar na textualidade oral recursos expressivos, procedimentos e técnicas como fonte de sua criação artística. Essa disposição de

38. AUGUSTO, 1995, p. 48-49. 
Solano, pouco contemplada em seus dias, é hoje recorrente na criação literária e performática e motivo de reflexão. Esse olhar e essa escuta nos oferecem poderosos veículos de interlocução, ao nos remeter, por exemplo, a toda uma poieses da memória performática dos cânticos sagrados e das falas cantadas no contexto dos rituais, em particular no âmbito dos sistemas religiosos, tanto nos de ascendência nagô-iorubá, quanto nas matrizes bantu.

O estudo dessa textualidade realça a inscrição da memória africana no Brasil em vários domínios: nos feixes de formas poéticas, rítmicas e de procedimentos estéticos e cognitivos fundados em outras modulações da experiência criativa; nas técnicas e gêneros de composição textuais; nos métodos e processos de resguardo e de transmissão do conhecimento; nos atributos e propriedades instrumentais das performances, nas quais o corpo que dança, vocaliza, performa, grafa, escreve. Dentre esse repertório formal e processual, Antônio Risério destaca os orikis, forma poética nagô-iorubá, como uma das muitas artes da palavra transplantadas da África:

O oriki nasce no interior da rica malha de jogos verbais, de ludi linguae, que se enrama no cotidiano ioruba. (...) A expansão de uma célula verbal é fenômeno comum no mundo dos textos. Jolles fala de provérbios que se expandem até se converterem em longos poemas proverbiais. Coisa semelhante se passaria entre o oriki-nome e o oriki-poema, com o nome atributivo se expandindo verbalmente em direção ideal à constituição de um corpo sígnico claramente percebido e definido como "poético". (...) Na verdade, a expressão "oriki" designa nomes, epítetos, poemas. Cobre portanto de uma ponta a outra o espectro da criação oral em plano poético. ${ }^{39}$

No oriki-poema, Risério observa a expansão de uma célula temática mínima que se desdobra e se expande, "agregando outras unidades que a ela se vinculam por laços de parentesco lingüístico, ou por afinidades sintáticas"; "o giro hiperbólico da palavra"; as imagens "amplas, coruscantes e contundentes”; o insólito das metáforas, a nominação encadeada "de uma série de sintagmas que, dispostos em seqüência ou justapostos, atualizam um paradigma do excesso", configurando a fisionomia do objeto recriado; a técnica de encaixes e o jogo de intertextualidades descentradas, emoldurados pelo pulso da composição paratática. ${ }^{40} \mathrm{Na}$ paisagem

39. RISÉRIO, 1996, p. 35.

40. RISÉRIO, 1996, p. 36 
textual de reminiscência banto, outras formas poéticas não apenas recriam, na ordem dos enunciados, a memória das diásporas africanas no Brasil, como também a inscrevem, como responsos, nas técnicas e performances de muitos gêneros narrativos, nas treliças da enunciação criativa da palavra e dos jogos poéticos de linguagem, transcriando a memória de muitos saberes estéticos, de outras dicções e fraseados, de outras nervuras poéticas. Resguardados nos acervos da memória, vibrantes em belíssimos cânticos e contos, performados em variados timbres vocais e rítmicos, esses engenhosos e múltiplos repertórios inscrevem na grafia da voz e nos rizomas das aletrias os variados trânsitos e cruzamentos poéticos diversos de nossa oralitura.

Quer realcemos os motivos temático-existenciais étnicos, as configurações de contextos sócio-econômicos, o manejo das várias heranças retóricas e estéticas, das diferentes matrizes discursivas e performáticas, os engenhos e modos de representação, as técnicas de composição, e toda a variada gama de elementos e aspectos configurados na e pela criação literária; a abordagem dessa complexa zona de produção textual, que alude à negrura como uma episteme plural e polivalente e à africanidade como um amplo espectro e território de matizes, linguagens e saberes, oferece-nos um vasto e rico repertório para nossa reflexão e deleite. E demandam um olhar e uma escuta perquiridores que nos possibilitem ouvir, no âmbito da literatura brasileira, os múltiplos cruzamentos de tradições estéticas e poéticas, de ritmos e dicções, de cadências e matizes, de vozes e fraseados que nos textos se divertem, dentre eles os que ostentam e traduzem a nossa afro-descendência.

A textualidade afro-brasileira, nos variados âmbitos em que vivifica, oferece-nos um amplo feixe de possibilidades de percepção, de pesquisa e de fruição, caligrafando a história e a memória dos sujeitos e das diversas opções textuais que a inscrevem na cartografia estética de nossa cultura. Como afrografias, nos voltejos vocais, nas gargantas das pautas ou nas espirais do corpo, essa literatura traduz-se em lumes e saberes. Fina lâmina da palavra ou delicado gesto é palavra possante, inventariante, livre. Litera e litura. Gravuras da letra e da voz. Afinal

Toda história é sempre sua invenção e toda memória um hiato no vazio ${ }^{41}$

41. MARTINA, 1999, p. 4 
Abstract: This essay aims to outline some aspects of Afro-Brazilian literary production and some current criticism underlying it, in order to offer some theoretical contributions to the debate and investigations of this production. Key words: Afro-Brazilian literature, Literary criticism, Black literature, Oraliture and performance.

\section{Referências Bibliográficas}

AUGUSTO, Ronald. Transnegressão. In: Presença negra no Rio Grande do Sul. Porto Alegre: Secretaria Municipal de Cultura, 1995.

ALEIXO, Rique. Viagem à textualidade afro-mineira. Suplemento Literário de Minas Gerais, Belo Horizonte, 7 jan. 1989.

ALVES, Miriam. Pedaços de mulher. Entrevista. In: MARTINS, Leda Maria; DURHAM, Carolyn; PERES, Phylis; HOWELl, C. (Ed.). Callaloo, v. 18, n. 4, African Brazilian Literature, an special issue. Baltimore: John Hopkins University Press, 1995.

ALVES, Miriam; DURHAM, Carolyn (Ed.). Finally us. Colorado Springs: Three Continental Press, 1995.

ASSIS, Machado. Reliquias da casa velha. Rio de Janeiro: Ed. Civilização Brasileira, 1995.

BARRETO, Lima. Clara dos Anjos. In: Histórias e Sonhos. Rio de Janeiro e Belo Horizonte: Livraria Garnier, 1990.

BASTIDE, Roger. Poesia afro-brasileira. São Paulo: Martins Fontes, 1943.

BERND, Zilá. Negritude e literatura na América Latina. Porto Alegre: Mercado Aberto, 1987.

BERND, Zilá (Org.). Poesia negra brasileira, antologia. Porto Alegre: Instituto Estadual do Livro/ Ed. AGE/ Ed. IGEL,1992.

CADERNOS NEGROS, v. 7, 1984. São Paulo: Quilombhoje, 1984.

CAMARGO, Osvaldo. O negro escrito, apontamentos sobre a presença do negro na Literatura Brasileira. São Paulo: Secretaria de Estado da Cultura, 1987.

CAMARGO, Osvaldo. Literatura negra: fundamentos e conseqüências. Suplemento Literário, n. 1, 26 jul. 1986.

COLLINS, Patricia Hill. Black feminist thought, knowledge, consciousness, and the politics of empowerment. New York and London: Routledge, 1991.

CRUZ E SOUZA, João da. Poesias completas. São Paulo: Edições de Ouro, 1982.

CUTI. Ela. In: CAMARGO, Osvaldo. O negro escrito, apontamentos sobre a presença do negro na Literatura Brasileira. São Paulo: Secretaria de Estado da Cultura, 1987. p. 200-202.

DUARTE, Eduardo de Assis; SCARPELlI, Marli Fantini. Poéticas da diversidade. Belo Horizonte: UFMG/FALE/POSLIT, 2002.

EVARISTO, Conceição. Eu-Mulher. In: Finally us. Colorado Springs: Three Continental Press, 1995. 
EVARISTO, Conceição. A noite não adormece nos olhos das mulheres. Ao escrever. Cadernos negros, v. 19, Poemas Afro-Brasileiros. São Paulo: Quilombhoje/Editora Anita, 1996.

GAMA, Luiz. Trovas Burlescas. 3. ed. São Paulo: Bentley Jr., 1904.

GUIMARÃES, Geni. Verso nu. Constatação. In: Finally us, Colorado Springs: Three Continental Press, 1995.

LUCINDA, Elisa. Aviso da lua que menstrua. In: O semelhante. Rio de Janeiro: Record, 2000.

MARTINS, Leda Maria. A cena em sombras. São Paulo: Perspectiva, 1995.

MARTINS, Leda Maria. Afrografias da memória. São Paulo: Perspectiva, Belo Horizonte: Mazza Edições, 1997.

MARTINS, Leda Maria; PERES, Phylis, DURHAM, Carolyn; HOWELL, Charles (Ed.). Callaloo, v. XVIII, n. 4. Baltimore: John Hopkins University Press, 1995.

MARTINS, Leda Maria. Os dias anônimos. Rio de Janeiro: Editora Sette Letras, 1999.

MORRISON, Toni. Playing in the dark, whiteness and the literary imagination. Cambridge and London: Harvard University Press, 1992.

MUNANGA, Kabengele. Negritude, usos e sentidos. São Paulo: Ática, 1986.

PEREIRA, Edimilson de Almeida. Nós, os Bianos. Belo Horizonte: Mazza Edições, 1996.

RIBEIRO, Esmeralda. Guarde segredo. Cadernos negros, n. 14, contos. São Paulo: Quilombhoje, 1991.

RIBEIRO, Esmeralda. Continente sem fim. In: Finally us, Colorado Springs: Three Continental Press, 1995.

RISÉRIO, Antônio. Oriki orixá. São Paulo: Perspectiva, 1996.

RISÉRIO, Antõnio. Textos e tribos. Rio de Janeiro: Imago, 1993.

SOUZA, Florentina. Quilombo de palavra. In: CONCEIÇÃO, Jônatas; BARBOSA, Lindinalva (Org.). Quilombo de palavras, a literatura dos afro-descendentes. 2. ed. Salvador: CEAO/UFBA, 2000.

TRINDADE, Solano. O poeta do povo. São Paulo: Cantos e Prantos Editora, 1999.

VENTURA, Adão. A cor da pele. Belo Horizonte: Edição do Autor, 1980.

XAVIER, Arnaldo. Balada apocalírica n. 1. In: BERND, Zilá (Org.). Poesia negra brasileira, antologia. Porto Alegre: Instituto Estadual do Livro/ Ed. AGE/ Ed. IGEL, 1992. p. 128-9. 